\title{
PERAN TEKNOLOGI INFORMASI PADA PEMBELAJARAN IPS
}

\author{
Elisa Dewi Juliyati \\ Email: 1810111220013@mhs.ulm.ac.id \\ Program Studi Pendidikan Sejarah Fakultas Keguruan dan Ilmu Pendidikan \\ Universitas Lambung Mangkurat \\ Banjarmasin
}

\begin{abstract}
Abstrak
Perkembangan teknologi informasi yang semakin pesat di era globalisasi saat ini tidak bisa dihindari lagi pengaruhnya terhadap dunia pendidikan. Tuntutan global menuntut dunia pendidikan untuk selalu dan senantiasa menyesuaikan perkembangan teknologi terhadap usaha dalam peningkatan mutu pendidikan, terutama penyesuaian penggunaannya bagi dunia pendidikan khususnya dalam proses pembelajaran. Teknologi informasi merupakan perkembangan sistem informasi dengan menggabungkan antara teknologi komputer dengan telekomunikasi. Adapun teknologi informasi dan komunikasi secara umum bertujuan untuk membuat siswa memahami perangkat teknologi informasi dan komunikasi secara umum, termasuk komputer dan literasi informasi, yang artinya siswa mengenali istilah yang digunakan dalam teknologi informasi dan komunikasi. Penulisan ini yaitu untuk mengetahui peran teknologi informasi dan komunikasi. yaitu sebagai suplemen, komplemen, dan substitusi.
\end{abstract}

\section{PENDAHULUAN}

Sekarang kita telah memasuki zaman modern dimana semua aspek kegiatan dapat dilakukan melalui teknologi dengan memanfaatkan internet sebagai penghubung antar wilayah. Salah satu aspek yang tak luput terkena pengaruh dari canggihnya teknologi yaitu aspek pendidikan. Pendidikan sebagai salah satu bagian yang tidak terpisahkan dalam proses pendewasaan manusia tentu memiliki andil yang cukup besar bagi bidang ilmu pengetahuan, namun disisi lain teknologi perlu dimanfaatkan untuk kemajuan dalam memperoleh informasi serta mencapai tujuan secara efektif dan efisien.

Kondisi perkembangan pada masa kini telah menjadi perspektif dalam kurikulum 2013. Koridor pembelajaran telah dikembangkan dalam kurikulum 2013 agar peserta didik menjadi peserta didik jamannya, sesuai dengan karakteristik era kini, yaitu aktif, kreatif, dan inovatif. Sesuai hakekat keilmuan yang ilmiah. Pembelajaran IPS selalu mendapat sorotan terkait dengan peran guru dan kondisi peserta didik. Guru masih memegang kendali utama pembelajaran, sedang peserta didik hanya mengikuti arahan guru. Ironisnya peserta didik menghapal dan mengerjakan perintah-perintah Guru. Kondisi ini harus direnovasi karena kurang sejalan dengan tuntutan jaman dan tuntutan kurikulum 2013 (Putro 2013:39). 
Guru IPS di SMP umumnya bukan berlatar belakang pendidikan sarjana guru IPS, namun sarjana pendidikan jurusan sejarah, ekonomi, geografi atau sosiologi. Perlu adanya usaha yang kuat dari guru untuk menemukan, metode yang sesuai dalam pembelaharan IPS, khususnya materi yang berhubungan dengan sejarah. Kesesuaian metode dengan materi, akan membuka pintu tujuan pembelajaran tercapai. Selama ini dalam pembelajaran sejarah, banyak peserta didik mengantuk dan diam terpaku seperti kembali ke masa kejadian masa lampau. Ini karena metode ceramah tidak banyak menyediakan ruang bagi peserta didik untuk turut ambil bagian. Diperparah dengan kurangnya perbendaharaan guru mengenai metode pembelajaran, menjadi kendala dalam mengajarkan materi sejarah.

Kegiatan belajar bukanlah semata-mata menyampaikan materi pelajaran. Proses belajar hendaknya mengubah cara pandang dan pemahaman setiap peserta didik juga mampu memiliki empati mengenai perjuangan masa lampau. Setiap mata pelajaran memiliki sasaran dampak yang akan dicapai, IPS mengandung salah satu tujuan agar peserta didik memiliki kemampuan komitmen dan kesadaran terhadap nilai-nilai sosial dan kemanusiaan. Dengan demikian, hendaknya setelah pembelajaran IPS, meninggalkan rasa yang membelenggu peserta didik atas kejadian tersebut, sehingga menimbulkan minat lebih dalam lagi untuk mau menggalinya.

Materi pelajaran IPS yang bertemakan sejarah, memerlukan metode yang membawa emosi peserta didik untuk bersimpati, empati, dan bahagia. Membangkitkan pastisipasi peserta didik sangat sulit jika menerapkan metode ceramah satu arah. Untuk itu, perlu diperlukan metode diskusi dan bermain peran yang membuat peserta didik gembira, memahami makna perjuangan dari berbagai daerah berbantuan media kamera dan audio visual. Hal ini sangat mudah dipahami oleh peserta didik, dan menarik keinginan peserta didik untuk mempelajari lebih dahsyat lagi. Dengan penggunaan teknologi dalam kegiatan belajar mengajar dapat merangsang minat peserta didik untuk mau belajar dengan cara kekinian.

Perkembangan teknologi informasi yang semakin pesat di era globalisasi saat ini tidak bisa dihindari lagi pengaruhnya terhadap dunia pendidikan. Tuntutan global menuntut dunia pendidikan untuk selalu dan senantiasa menyesuaikan perkembangan teknologi terhadap usaha dalam peningkatan mutu pendidikan, terutama penyesuaian penggunaannya bagi dunia pendidikan khususnya dalam proses pembelajaran. Teknologi informasi merupakan perkembangan sistem informasi dengan menggabungkan antara teknologi komputer dengan telekomunikasi (Baharudin, 2010).

Adanya perkembangan teknologi dan informasi dalam dunia pendidikan, maka pada saat itu sudah dimungkinkan untuk diadakan belajar jarak jauh dengan menggunakan media internet untuk menghubungkan antara peserta didik dan pendidik, melihat nilai peserta didik secara online, mengecek keuangan, melihat jadwal kuliah, mengirimkan berkas tugas yang diberikan guru dan sebagainya. Perubahan akan tuntutan itulah yang menjadikan dunia pendidikan memerlukan inovasi dan kreativitas dalam proses pembelajarannya 
karena banyak orang mengusulkan dalam pendidikan khususnya pembelajaran, akan tetapi sedikit sekali orang berbicara tentang solusi pemecahan masalah tentang proses belajar dan mengajar yang sesuai dengan tuntutan global abad ke 21 saat ini.

\section{PEMBAHASAN}

\section{Pembelajaran IPS}

Istilah "Ilmu Pengetahuan Sosial", disingkat IPS, merupakan nama mata pelajaran di tingkat sekolah dasar dan menengah atau nama program studi di perguruan tinggi identik dengan istilah "social studies" (Sapriya 2009: 19). Istilah IPS di sekolah dasar merupakan nama mata pelajaran yang berdiri sendiri sebagai integrasi dari sejumlah konsep disiplin ilmu sosial, humaniora, sains bahkan berbagai isu dan masalah sosial kehidupan. Materi IPS untuk jenjang sekolah dasar tidak terlihat aspek disiplin ilmu karena lebih dipentingkan adalah dimensi pedagogik dan psikologis serta karakteristik kemampuan berpikir peserta didik yang bersifat holistik. IPS adalah suatu bahan kajian terpadu yang merupakan penyederhanaan, adaptasi, seleksi dan modifikasi diorganisasikan dari konsep-konsep ketrampilanketrampilan Sejarah, Geografi, Sosiologi, Antropologi, dan Ekonomi (Puskur, 2001: 9). (Fakih Samlawi \& Bunyamin Maftuh 1999: 1) menyatakan bahwa IPS merupakan mata pelajaran yang memadukan konsep-konsep dasar dari berbagai ilmu sosial disusun melalui pendidikan dan psikologis serta kelayakan dan kebermaknaannya bagi siswa dan kehidupannya.

Pembelajaran IPS lebih menekankan pada aspek "pendidikan" dari pada transfer konsep karena dalam pembelajaran IPS siswa diharapkan memperoleh pemahaman terhadap sejumlah konsep dan mengembangkan serta melatih sikap, nilai, moral dan ketrampilannya berdasarkan konsep yang telah dimilikinya. IPS juga membahas hubungan antara manusia dengan lingkungannya. Lingkungan masyarakat dimana anak didik tumbuh dan berkembang sebagai bagian dari masyarakat dan dihadapkan pada berbagai permasalahan di lingkungan sekitarnya. Berdasarkan uraian di atas peneliti menyimpulkan bahwa pembelajaran IPS sebagai proses belajar yang mengintegrasikan konsep-konsep terpilih dari berbagai ilmu-ilmu sosial dan humaniora siswa agar berlangsung secara optimal.

\section{Teknologi Informasi}

Perkembangan peradaban manusia diiringi dengan perkembangan cara penyampaian informasi yang selanjutnya dikenal dengan istilah Teknologi Informasi. Pada awalnya Teknologi Informasi dikembangkan manusia pada masa pra sejarah dan berfungsi sebagai sistem untuk pengenalan bentuk-bentuk yang mereka kenal, mereka menggambarkan informasi yang mereka dapatkan pada dinding-dinding gua, tentang berburu dan binatang buruannya. Sampai saat ini teknologi informasi terus terus berkembang tetapi penyampaian dan bentuknya sudah lebih modern. 
Teknologi informasi adalah suatu teknologi berupa (hardware, software, useware) yang digunakan untuk memperoleh, mengirimkan, mengolah, menafsirkan, menyimpan, mengorganisasikan, dan menggunakan data secara bermakna untuk memperoleh informasi yang berkualitas. Teknologi Informasi sebagai media pendidikan dilakukan dengan menggunakan media-media komunikasi seperti telepon, komputer, internet, email, dan sebagai berikut. Interaksi antara pendidik dan peserta didik tidak hanya dilakukan melalui hubungan tatap muka tetapi juga dilakukan dengan menggunakan media-media tersebut.

\section{Peran Teknologi Informasi Pada Pembelajaran IPS}

Sebagai bagian dari pembelajaran, teknologi informasi yang memiliki beberapa

peran, yaitu sebagai suplemen, komplemen, dan substitusi. Pertama, peran tambahan (suplemen) dikatakan berfungsi sebagai suplemen atau tambahan, apabila peserta didik mempunyai kebebasan memilih, apakah akan memanfaatkan materi pembelajaran melalui teknologi informasi atau tidak. Dalam hal ini, tidak ada kewajiban atau keharusan bagi peserta didik untuk mengakses materi pembelajaran melalui teknologi informasi. Sekalipun sifatnya hanya opsional, peserta didik yang memanfaatkannya tentu akan memiliki tambahan pengetahuan atau wawasan. Walaupun materi pembelajaran melalui teknologi informasi berperan sebagai suplemen, para guru tentunya akan senantiasa mendorong, mengggugah, atau menganjurkan para peserta didiknya untuk mengakses materi pembelajaran melalui teknologi informasi yang telah disediakan.

Kedua, Peran Pelengkap (Komplemen) dikatakan berfungsi sebagai komplemen atau pelengkap, apabila materi pembelajaran melalui teknologi informasi diprogramkan untuk melengkapi materi pembelajaran yang diterima peserta didik di dalam kelas. Sebagai komplemen berarti materi pembelajaran melalui teknologi informasi diprogramkan untuk menjadi materi reinforcement atau pengayaan yang bersifat enrichment atau remedial bagi peserta didik di dalam mengikuti kegiatan pembelajaran konvensional.

Ketiga, Peran Pengganti (substitusi) beberapa sekolah di negara-negara maju memberikan beberapa alternatif model kegiatan pembelajaran kepada para siswanya. Tujuannya adalah untuk membantu mempermudah para siswa mengelola kegiatan pembelajaran sehingga para siswa dapat menyesuaikan waktu dan aktivitas lainnya dengan kegiatan pembelajaran. Disinilah letak perbedaan antara guru sekarang yang telah menggunakan teknologi informasi dengan guru tradisional. Kita sebagai guru abad 21 guru yang telah menggeser paradigma pembelajaran dari pembelajaran yang berpusat pada guru (teacher-centered learning) menuju pembelajaran yang berpusat pada siswa (studentcentered learning) dimana lebih berperan sebagai perancang pembelajaran, fasilitator, pelatih dan manajer pembelajaran. Bukan sebagai pusat informasi dan satu-satunya sumber belajar, yang maha tahu. Oleh karena itu, guru harus mampu mendesain pembelajaran atau menyusun rencana pelaksanaan pembelajaran (RPP) yang mencirikan paradigma baru pembelajaran seperti dijelaskan di atas dengan mengintegrasikan teknologi informasi sebagai sarananya. 


\section{SIMPULAN}

Perkembangan teknologi informasi yang semakin pesat di era globalisasi saat ini tidak bisa dihindari lagi pengaruhnya terhadap dunia pendidikan. Tuntutan global menuntut dunia pendidikan untuk selalu dan senantiasa menyesuaikan perkembangan teknologi terhadap usaha dalam peningkatan mutu pendidikan, terutama penyesuaian penggunaannya bagi dunia pendidikan khususnya dalam proses pembelajaran. Dalam dunia pendidikan, bertujuan agar peserta didik memahami secara umum, termasuk komputer dan memahami informasi, artinya peserta didik mengenal istilah-istilah yang digunakan pada teknologi informasi dan komunikasi. Peran teknologi informasi dalam pembelajaran, selain membantu peserta didik dalam belajar juga memiliki peran yang cukup berpengaruh bagi guru terutama dalam pemanfaatan fasilitas untuk kepentingan memperkaya kemampuan mengajarnya.

\section{REFERENSI}

Anis, M. Z. A., Putro, H. P. N., Susanto, H., \& Hastuti, K. P. (2020). Historical Thinking Model in Achieving Cognitive Dimension of Indonesian History Learning. PalArch's Journal of Archaeology of Egypt/Egyptology, 17(7), 7894-7906.

Baharudin, R. (2010). Keefektifan Media Belajar Berbasis Teknologi Informasi Dan Komunikasi. Tadrîs, 5(1), 112-127.

\section{Susanto, H. (2020). PEDAGOGI SEJARAH, NASIONALISME DAN KARAKTER} BANGSA.

Susanto, H. (2020). Profesi Keguruan. Banjarmasin: FKIP Universitas Lambung Mangkurat.

Susanto, H., \& Akmal, H. (2018). Efektivitas Penggunaan Aplikasi Pembelajaran Berbasis Mobile Smartphone Sebagai Media Pengenalan Sejarah Lokal Masa Revolusi Fisik Di Kalimantan Selatan Pada Siswa Sekolah Menengah Atas. HISTORIA: Jurnal Program Studi Pendidikan Sejarah, 6(2), 197-206.

Susanto, H., Irmawati, I., Akmal, H., \& Abbas, E. W. (2021). Media Film Dokumenter Masuknya Islam Ke Nusantara dan Pengaruhnya Terhadap Keterampilan Berpikir Kritis Siswa. HISTORIA: Jurnal Program Studi Pendidikan Sejarah, 9(1).

Syaharuddin, S., \& Susanto, H. (2019). Sejarah Pendidikan Indonesia (Era Pra Kolonialisme Nusantara sampai Reformasi). Banjarmasin: FKIP Universitas Lambung Mangkurat. 
Samlawi, Fakih \& Bunyamin Maftuh. (1999). Konsep Dasar IPS. Depdikbud: Dirjend. Dikti

Sapriya. (2009) Pendidikan IPS. Bandung: Rosda Karya.

Puskur. (2001). Kurikulum Berbasis Komperensi, Mata Pelajaran Sains Sekolah Dasar. Jakarta. Kompas.

Putro, H. P. N. (2013). Pengembangan Pembelajaran IPS dalam Kurikulum 2013. Mewacanakan Pendidikan IPS, 39. 